\title{
Exploration on Practice of Course-certificate Integration in Course Reform of Tour Guide Business
}

\author{
Yan Li \\ Yiwu Industrial and Commercial College, Yiwu, 322000, China
}

\begin{abstract}
Keywords: Course-certificate integration, Tour guide business, Course reform, Practice
\end{abstract}
\begin{abstract}
The rapid development of tourist industry has put forward requirements for high quality of tour guide talents. As a core skill course of tour guide major in higher vocational colleges, Tour Guide Business is strongly practical. The course reform with course-certificate integration can train tour guide talents meeting the demand of the society and post and achieve effective connection of talent supply and demand in colleges and universities and tourist market.
\end{abstract}

\section{Introduction}

Talent quality is key to social development. The rapid development of the society and great demand of tourist market require graduates majoring in tour guide in higher vocational colleges to integrate into the society rapidly after graduation and make due contributions to the development of tourist business. The Ministry of Education proposed to advocate the concept of paying equal attention to academic certificate and vocational certificate in higher vocational colleges and implement "dual-certificate system" in the educational work in 2010. With the emergence of "dual-certificate system", higher vocational colleges should adopt the training mode of combining vocational education certificate and professional certificate and make talent training standard and employment criteria of enterprises corresponding to each other, which is a correct way to train readily marketable professional talents.

\section{Course nature and functions of Tour Guide Business}

Tour guide business is one of the core tasks of travel agencies and essential skill and ability of tour guides. As the foundation of training tour guide talents and a core course, Tour Guide Business teaches students how to become a qualified tour guide and supports the training of students' professional ability. This course is also a compulsory course of national tour guide qualification test. Therefore, it becomes a professional core course with strong practicalness offered for tour guide major in higher vocational colleges.

The training objective of Tour Guide Business course is to train high-quality skilled talents adapted to the demand of modern tourism and having good professional ethics and front-line post service abilities such as escort-service guide, local guide, leader and tourist attractions (i.e. one profession + multiple abilities + comprehensive quality) with serving local economic development as the purpose. The reform practice of Tour Guide Business course trains actual work abilities of students and achieves objectives in knowledge, ability and quality with the mode of close combination of course, certificate and post and cooperation of government, schools and enterprises. (1) Knowledge objective. Students are required to understand the basic concept, classification, work responsibilities, guide service quality standard, guide interpretation and service skills of tour guide and master required theoretical knowledge of a qualified tour guide and the procedure and standard management knowledge of various guider services. (2) Ability objective. Students are required to conduct people-oriented and personalized services on the basis of providing standard services for tourists, master operating skills such as team guide, interpretation and travel life services and improve their guide interpretation ability, guide service ability, organization and coordination ability, ability of analyzing and solving problems and the ability of coping stress and crisis. (3) Quality objective. 
Students are required to have good professional ethics and healthy physical and psychological quality, improve their emotion and etiquette and train their team spirit and abilities of cooperation in work.

\section{Problems existing in course teaching of Tour Guide Business}

According to the current situation of tour guide talent training and classroom teaching, the obtainment of tour guide qualification certificate and classroom teaching of Tour Guide Business are divorced, mainly manifested in repeated teaching contents, different evaluation and single means of classroom teaching.

\section{Repeated teaching contents}

The obtainment of tour guide qualification certificate has become one of the elements that tourism enterprises pay attention to during the employment of tour guide talents. To improve the employment competitiveness of graduates majoring in tour guide, Tour Guide Business which is one of the compulsory subjects for tour guide qualification certificate should complete teaching in talent training and certificate training before the examination for certificate. They have the same teaching materials and consistent contents. Even teachers are the same. Though the original intention of teachers is to increase the passing rate, but it undoubtedly causes waste of time and energy of teachers and students. What is more, it causes students to pin their hope on pre-test training in classroom teaching process. During the training, they think that they've learnt the knowledge. Finally, they fail to cherish classroom teaching, thus producing a result contrary to the expected objective.

\section{Mismatch between evaluation standards}

The assessment of classroom teaching and qualification certificate evaluation are not integrated and evaluation standards mismatch with each other. Currently, the assessment of Tour Guide Business course mainly involves independent proposition of teachers and self-evaluation. Due to limit of conditions, the final result of a course is obtained by usual result plus examination paper result. However, the examination and evaluation of tour guide qualification certificate are conducted by each province authorized by the state uniformly. For students, there are different evaluation methods for the same course and same contents, which easily causes students' selective understanding, deviation in requirements of Tour Guide Business course for knowledge, skills and ability and deviation and even misunderstanding of occupational cognition.

\section{Single teaching means}

Influenced by traditional classroom teaching thought, teachers only repeat what the book says and impart knowledge to students by making PPT. The single classroom teaching mode - "teachers tell and students listen" and "teachers set an example and students imitate" in practice and training course causes students in the state of passive knowledge reception. To attract the attention of students, teachers spend a lot of time and energy in making beautiful PPT and optimizing this single medium to the greatest extent. However, PPT teaching means is commonly seen by students and cannot closely combine classroom teaching and work. For example, steps and contents are listed perfectly in the elaborate courseware during classroom teaching of the work process of tour guide. However, students are indifferent to practical operation. One experience of team guide can achieve the same effect as one-month course study.

\section{Practice plan of "course-certificate integration" in Tour Guide Business course reform}

\section{Implementing principles}

\section{Follow practical utility}

The implementation of teaching reform of "course-certificate integration" makes teachers' teaching more pertinent and students' study more purposeful. The knowledge learnt in class is required for the obtainment of certificate and employment post. It can allow students to be qualified 
for the post with academic certificate and occupational qualification certificate, achieve "zero distance" with post and improve professional competitiveness of students.

Integrate "certificate" into "course" and focus on "course"

Teaching reform of course-certificate integration first requires the use of standards and requirements of occupational qualification (post) and qualification certificate as the main line in the reconstruction of course teaching contents, the completion of contents that should be known in theoretical teaching classroom and skillful mastery of contents that should be mastered in practical teaching link. Therefore, it is necessary to investigate demands of target enterprises or industry, determine accurate demands of a post for knowledge, ability, skills and professional quality, integrate or decompose occupational abilities according to the standard of course system framework, complete the reconstruction of teaching contents based on the original course content and produce a new course.

Combine teachers' leading role and student subject

Practicalness is an important feature of course teaching in higher vocational colleges as well as important significance of teaching reform practice of course-certificate integration. Therefore, course teaching of Tour Guide Business requires changing teacher subject into teacher's leading role and student object into student subject and stimulating students' learning initiative and enthusiasm through project teaching and task-driven methods. In this way, teachers become instructors of teaching and students become the subject of knowledge obtainment. Meanwhile, the close integration of post, course and certificate is achieved and talent training quality of higher vocational colleges is improved.

\section{Implementation plan}

\section{Reconstruction of course contents of Tour Guide Business}

As a core professional skill course for tour guide major, Tour Guide Business uses teaching materials verified by Zhejiang Tourist Administration. To avoid repetition with certificate training, teaching in the first stage is completed within the first academic year after students enter the school with the reconstruction of course contents and the method of module subdivision (see table 1).

Table 1. Module subdivision of Tour Guide Business course

\begin{tabular}{|c|c|c|}
\hline \multirow{4}{*}{$\begin{array}{l}\text { Tour guide } \\
\text { business }\end{array}$} & $\begin{array}{l}\text { Relevant legal provisions and rules } \\
\text { and regulations in tourism industry }\end{array}$ & $\begin{array}{l}\text { Tourism Law of the People's Republic of China } \\
\text { Regulations of Travel Agencies and Rules for Implementation } \\
\text { of Regulations of Travel Agencies } \\
\text { Passport Law of the People's Republic of China } \\
\text { Provisions of Customs of the People's Republic of China on } \\
\text { Administration of Luggage of Chinese Tourists during Entry } \\
\text { and Exit } \\
\text { Regulations on Administration of Tour Guides } \\
\text { Outbound Travel Service Quality of Travel Agencies } \\
\text { Requirements for Domestic Travel Service Quality of Travel } \\
\text { Agencies } \\
\text { Service Quality of Tour Guides }\end{array}$ \\
\hline & $\begin{array}{l}\text { Relevant knowledge of tour guide } \\
\text { business }\end{array}$ & $\begin{array}{l}\text { Professional knowledge of travel agencies } \\
\text { Tourist communications service knowledge } \\
\text { Currency and insurance knowledge } \\
\text { Entry and exit knowledge } \\
\text { Luggage business of travel agencies }\end{array}$ \\
\hline & Handling of problems and accidents & $\begin{array}{l}\text { Handling of business, personal and safety accidents } \\
\text { Handling of emergencies }\end{array}$ \\
\hline & $\begin{array}{l}\text { Service procedure and comprehensive } \\
\text { service skills of tour guide }\end{array}$ & $\begin{array}{l}\text { Service procedure of escort-service guide, local guide, leader, } \\
\text { tourist attraction and individual traveler guide } \\
\text { Skills of team guide, cooperation and language } \\
\text { Services for special tourist groups }\end{array}$ \\
\hline
\end{tabular}


Certificate training in the second stage of Tour Guide Business should focus on the examination and course contents should not be repeated.

In practical improvement training in the third stage of Tour Guide Business, students can conduct substituted post exercitation in travel agencies and tourist attractions subject to school-enterprise cooperation in busy season of tourism and return to school to learn the course in slack season of tourism so as to improve their professional connotations as tour guide.

Implementation of teaching mode involving "learning and working alteration" and "entry in busy season and out in slack season"

Substituted post exercitation of tour guide major strictly follows "busy and slack seasons" of tourist activities. It is different from other majors. In busy season of tourism, tourist enterprises need a lot of tour guides for providing services for tourists. This is a great opportunity for substituted post exercitation of students majoring in tour guide. In slack season of tourism, tourist enterprises break the pale and will not accept students for substituted post exercitation. At this time, students can return to school to continue their study. Therefore, the practical teaching mode for tour guide major involving "learning and working alteration" and "entry in busy season and out in slack season", i.e. students stay in the workplace in busy season and classroom in slack season, is good for improving the efficiency of substituted post exercitation and can improve students' professional cognition and abilities rapidly and allow classroom teaching and post practical supplement each other.

Enhance practical teaching and fuzz up the concept of classroom and workplace

The explanation level of tour guides directly depends on their ability of oral expression. Students majoring in tour guide in higher vocational colleges are lively and active and often show zero barrier in the communication with classmates and teachers in class. However, they act overcautiously and dare not speak in public in the workplace. The reason is their lack of self-confidence and courage. For this weakness, Tour Guide Business course should enhance practical teaching and allow students to go out of the classroom and have lessons in urban street, tourist attractions and exhibition hall. Students can exercise guide interpretation in places with more people so as to fuzz up the concept of classroom and workplace, highlight their subjectivity and provide them with more chances of oral expression ability training. The practice of course reform proves that this is a good method for discovering talents and urging students to understand themselves correctly and improve self-confidence.

Keep up with features of "internet+" era and enrich classroom teaching means

The in-depth application of information technology in the field of education and teaching makes traditional classroom face great challenges. The traditional classroom teaching must be reformed so as to win victory in challenges. The focus of attention is teaching forms such as micro-course and flipped classroom. For the reform of classroom teaching of Tour Guide Business, it is required to use this major technical change positively, make full use of big data platforms and technologies such as micro-resources, micro-network, wechat, microblog and micro-video in combination with such resources as case, courseware, material and animation and achieve enjoyable classroom teaching.

In conclusion, talent training in higher vocational colleges adopts "course-certificate integration" teaching method in course design, implements the unification of three standards, i.e. consistency among classroom standard, industrial standard and certification standard, achieves seamless connection among government, schools and enterprises and professionalism of higher vocational talent training post, specialization of employees in industrial enterprises and standardization of certification requirements and finally solves the problem of mismatch between talent supply and demand in tourist market.

\section{Acknowledgments}

This paper is the result of class teaching reform research project of higher education in Zhejiang Province in 2013, named Design and Implementation of Course-certificate Integration in Class Teaching of Tour Guide Business, No. kg2013813. 


\section{References}

[1] Li Yan. Exploration on Process-oriented Assessment Mode in Verification of Occupational Skills of Students in Higher Vocational Colleges . Education and Vocation, 2013, (8)

[2] Cao Wentao. Study on Practice of Course-certificate Integration in Teaching of Higher Vocational Courses. Master's Thesis of Ningxia University, 2014

[3] Chen Baoxia. First Exploration on Teaching Reform of Tour Guide Business in Tourism Management Major . Education and Vocation, 2010, 06

[4] Zhu Lin. How to Connect Higher Vocational Specialized Course System and Vocational Qualification Certificate Effectively . Vocation, 2011, (4)

[5] Jiang Qunying, Lei Shiping, Dong Renzhong. Thinking on Promoting Chinese Employment Access System . Study on Vocational Education, 2004, (4) 